Ненад Нинковић

Универзитет у Новом Саду

Филозофски факултет

Одсек за историју

atanacko1749@gmail.com
Оригинални научни рад

примљено: 5. јул 2011

прихваћено: 1. октобар 2011

\title{
РЕФОРМА СРПСКОГ ШКОЛСТВА У ХАБЗБУРШКОЈ МОНАРХИЈИ 1769-1777*
}

Сажетак: Друга половина XVIII века време је значајних реформи у Хабзбуршкој монархији, које су између осталог спроведене и на просветном пољу. Њихова суштина огледала се у секуларизацији образовног система. Српски образовни систем је у овом периоду под утицајем реформских кругова из Беча, а у складу са централизаторском и германизаторском политиком царице Марије Терезије и њеног сина цара Јозефа II, такође реформисан, што су подржали православна јерархија и образованији Срби. Рад има тенденцију да прикаже како је текао процес реформисања образовног система код Срба, те законске акте који су га пратили.

Кључне речи: реформа школства, Allgemeine Schulordnung, Школски устав, Ratio educationis, основне школе, Теодор Јанковић Мирјевски, Стефан Вујановски, Аврам Мразовић.

У историји европског школства XVIII век, са рационализмом као доминатним филозофским правцем, има посебан значај. Идеја да образовање поседује довољну снагу да промени човека и реформише људско друштво потекла је од просветитељских мислилаца. Ово би истовремено била основа која би појединца требало да доведе, коришћењем сопственог разума, до врхунске среће, јер је, сматрали су просветитељи, дошло време људске зрелости, односно зрелости цивилизације. ${ }^{1}$ Полазећи од изнетих филозофских ставова и практичних потреба које је наметао технолошки развој, европски владари, пре свега пруски, хабзбуршки и руски, у другој половини XVIII века извршили су реформу школског система

\footnotetext{
* Рад је настао као фазни резултат републичког пројекта број 177002 под називом Војвођански простор у контексту европске историје.

${ }^{1}$ Иако просветитељство није кохерентан филозофски смер, једно је заједничко за све његове мислиоце сви су веровали да се преко науке и образовања може постићи много чак и са људима скромних интелектуалних способности, Метју С. Андерсон, Европа у осамнаестом веку 1713-1789, Београд 2003, 448-450; Stevan Hadživuković, Francusko prosvetiteljstvo odraz vere u ljudski napredak, Novi Sad 2005, passim.
} 
својих држава. Секуларизација школства била је суштина њихових реформи, до чијег спровођења је просвета била готово искључиво у рукама цркве, у Аустрији претежно у рукама језуита. Мада су они имали дугу традицију у образовању, почетком XVIII века стање у школству Хабзбуршке монархије било је веома лоше. ${ }^{2}$ И поред утицаја просветитеља и њихових ставова у вези са образовањем, број деце која су похађала основну школу био је веома низак, примера ради 1770. у Доњој Аустрији је свега је 17\% деце школског узраста похађало школу. ${ }^{3}$ У интересу владара и државе било је да преко школе васпитава добре грађане, али пракса је показала да то није било могуће док школом управља Црква, јер је схватање циља образовања било различито. Док је Црква пре свега желела да створи доброг хришћанина, држави је био потребан поданик чије би образовање поспешило економски развој и омогућило напредак војне технике. Потреба стварања добрих хришћана и даље је остала као један од задатака образовања, што је наглашавано у реформским актима и што није остало само формални захтев, али је и то подручје требало да контролише држава. ${ }^{4}$

Ниједан владар Хабзбуршке монархије пре царице Марије Терезије није толико пажње посветио образовању својих поданика као она. Реформу школства започела је отварањем школа које су биле изван утицаја језуита и које је требало да одговоре на конкретне практичне изазове, односно да дају одређени профил службеника, док би учитељи у њима постали државни чиновници који спроводе овакву образовну политику. ${ }^{5}$ Њен наредни корак на реформском путу било је оснивање Дворске школске комисије (Studienhofkommission) у Бечу 1760. која је постала централни школски орган. По завршетку Седмогодишњег рата (1756-1763) конкретније је приступила реформисању школства. У том послу, нарочито између 1764. и 1772, својим саветима и предлозима помагао јој је гроф Јохан Антон фон Перген, истичући неопходност секуларизације школства. ${ }^{6}$ Слично као што је већ урађено у Пруској приликом реформе школства, и у Бечу је отворена 1771. Нормална школа или Норма, која је радила на новим принципима и истовремено била основна школа, реалка и учитељска школа. Потом је уследило укидање

\footnotetext{
${ }^{2}$ Josef Schermaier, Geschichte und Gegenwart des allgemeinbildenden Schulwesens in Österreich, Wien 1990, 35-37.

${ }^{3}$ Joseph Alexander Helfert, Die Gründung der österreichischen Vollksschile durch Maria Theresia, Prag 1860, 63.

${ }^{4}$ Двор је 1751. тражио од Цркве извештај о стању у школама. Уследио је протест црквених власти које су сматрале да надзор над школама припада искључиво цркви. Двор је потом обавестио генералног викара да је образовање ствар просветне политике владе, а не цркве, чиме је прекинута даља расправа о овом питању, Димитрије Кириловић, Српске основне школе у Војводини у 18 веку (1740-1780), Сремски Карловци 1929, 19.

5 Занимљиво је да је царица Марија Терезија још пре отварања Хекерове Реалке основала 1746. Терезијанум, школу која је већ била изван језуитског утицаја. Ово је била прва школа која је требало да пружи практична знања и добре службенике, а поред ње, пре реформе школства, основана је још Оријентална школа 1754. у којој су образоване будуће дипломате, Derek Edvard Dawson Beales, Joseph II: in the shadow of Maria Theresia, 1741-1780, 1987, 455-456; Д. Кириловић, Српске..., 17.

6 Joseph Alexander Helfert, нав. дело, 181-241; Robert A. Kann, A history of the Habsburg Empire 1526-1918, Barkly - Los Angeles - London 1980.
} 
језуитског реда 1773. и прелазак њихове имовине у руке државе. Ово је био веома важан потез јер је њиме обезбеђена и материјална основа за даље спровођење реформи. Непосредно пре доношење самих законских аката Марија Терезија је лапидарно означила њихову суштину изјавивши 1773. „Das Schulwesen aber ist und bleibt allzeit ein Politicum “, односно означавајући државу као једину инстанцу која управља образовањем својих поданика. Угледајући се на Пруску у вези са реформом образовног система, ${ }^{7}$ иако према овој држави није имала симпатија, Марија Терезија je позвала опата Јохана Игнаца фон Фелбигера (Johann Ignaz von Felbiger, 1724-1788) да дође у Беч и изврши у Монархији реформу школства по угледу на ону коју је спровео у Пруској. Опат Фелбигер је одмах по доласку постао члан Дворске школске комисије и учитељ у Нормалној школи. ${ }^{8}$ Исте године (1774) израдио је план реформи основног образовања познат под називом Општа школска уредба за немачке нормалне, главне и тривијалне школе у наследним земљама (Allgemeine Schulordnung für die Deutschen Normal- Haupt- und Trivialschulen in den sämtlichen K. K. Erbländern. У даљем тексту Allgemeine Schulordnung), који је 6. децембра 1774. царица својим потписом санкционисала. На основу овог документа основно образовање постало је обавезно за сву децу, оба пола, а изводило се у три врсте школа:

1. Тривијалним, ${ }^{9}$ које су осниване пре свега у селима, али их је било и у мањим градовима. У њима је настава трајала годину или две, а учили су се читање, писање, рачунање и основе хришћанске вере (катихизис, а у неким и црквено појање).

2. Главне школе су биле друга врста основних школа, које су претежно осниване у градовима за ученике који су своје образовање желели да наставе у гимназијама. Прецизније говорећи, ове школе имале су два задатка: са једне стране, у њима су образовани ученици који своје школовање желе да наставе у гимназијама, док су, истовремено, за обављање практичних послова, пре свега за трговину и занатство, припремани они који су намеравали да после основне школе прекину школовање. Из тог разлога, предмети који су се у њој предавали, поред оних који су се слушали у тривијалним школама, били су још Немачки, Основе латинског, Историја, Географија, Механика, Тригонометрија и Архитектура.

3. Нормалне школе су основане у сваком окружном средишту и у њима су се образовали будући учитељи тривијалних школа. Предмети у овој школи у почетним годинама били су исти као у главним, а у завршном разреду усмерени су пре свега на педагошко образовање будућих учитеља. Предвиђено је да нико ко није

\footnotetext{
${ }^{7}$ Реформу пруског школства су спровеле две особе, за протестантске области то је учинио Јохан Јулијус Хекер, а за католичке опат Фелбигер, мада је основа школства код обојице била иста. За почетак реформи је заслужан Хекер јер је још 1748. отворио једну реалку (школа у којој су предавани нови предмети потребни пре свега за успешно вођење домаћинства и трговину), чиме је почела школска реформа у Пруској, Wolfgang Neugebauer, Schule und Absolutismus in Preussen, Berlin 1992, 45.

8 James Van Horn Melton, The Theresian School Reform of 1774, Early modern Europe, Malden-Oxford-Victoria 2006, 55-56.

${ }^{9}$ Назив тривијалне носиле су јер се у њима пре свега учило читање, писање и рачунање (Lesen, Schreiben und Rechnen), што је био својеврсни тривијум.
} 
завршио нормалну школу и о томе није имао писмену потврду школског директора није могао постати учитељ.

Следећи пруски узор, заведен је и нови систем контроле, односно надзора школа. Тривијалним школама надзорник је био месни парох. Изнад њега био је окружни инспектор који је надгледао тривијалне и главне школе, а био је хијерархијски испод школске комисије ${ }^{10}$ која је постојала у сваком округу. Крајња инстанца била је Дворска школска комисија, односно Генерална дирекција нормалних школа, основана у Бечу као њен саветодавни орган. ${ }^{11}$

Allgemeine Schulordnung је закон који је важио, како је већ истакнуто, за аустријске наследне земље, а истовремено је био основа за спровођење реформи изван Наследних земаља и за друге народе. Тако су реформе школства у Монархији нашле одраз и у реформи српског школства на простору под јурисдикцијом Карловачке митрополије. Утицај овог закона за српски народ у Хабзбуршкој монархији био је вишеструк, иако је он највећим делом живео изван граница Наследних земаља, већ по томе што је постао основа реформе српског школства. Штавише, у Војној граници, у којој су Срби чинили већину становништва, важили су закони донети за Наследне земље, тако је Allgemeine Schulordnung-ом решено питање српских школа у Војној граници на, у то време, најсавременијим принципима. Иако се реформа српског школства не може посматрати као одвојена целина већ само као одраз и саставни део реформи школског система читаве Монархије, али и целокупних терезијанско-јозефинистичких реформи, она у одређеној мери показује извесне специфичности. Пре свега, иако је двор био и њен иницијатор, спровођење је ишло преко црквене јерархије, које ју је, са мање или више одушевљења, прихватила и подржала. И када је реформа извршена, она је учињена са знањем јерархије Карловачке митрополије и све до закона којима је у другој половини XIX века наметнуто одузимање школа и утицаја Цркве у њима, она je бринула о основном образовању верника, али и средњошколском образовању, јер су српски епископи и митрополити били стални чланови гимназијских патроната и њихови значајни материјални приложници.

Своју дужу предисторију нема само реформа школства која је спровођена у Наследним земљама, она је, такође, уочљива и када је у питању српско школство. Она код Срба има два периода, један, који је приметан до Црквено-народног сабора из 1769. године и други, који почиње од овог сабора и завршава се 1777 , мада су и промене које су у школству наступиле после њега биле мале све до реформи Уроша Несторовића, односно до 1811. Реформе до 1769. су готово искључиво биле реформе које је спроводила црквена јерархија, али су оне биле више одраз потребе за образовањем верника, подизања културног нивоа српског народа, борбе против уније и покатоличавања, него жеље да се наметне нови систем. Иако су многи

\footnotetext{
${ }^{10}$ У ову школску комисију улазило је неколика саветника државне власти, заступник ординаријата (код католика је то члан бискупског управног суда), директор и секретар нормалне школе. Задатак јој је био да именује окружне школске надзорнике, издаје учитељске потврде, контролише испите, управља школским фондом, итд. О овоме: Д. Кириловић, Српске..., 22-23.

${ }^{11}$ James Van Horn Melton, The Theresian School Reform of 1774, 57-58.
} 
јерарси добро познавали водећи европски филозофски правац рационализам, чак и оправдавали поједине његове ставове у вези са образовањем, њихова акција је до митрополита Павла Ненадовића - а овде треба поменути двојицу његових претходника митрополите Мојсија Петровића и Вићентија Јовановића, те бачког епископа Висариона Павловића - била изолована у односу на остале народе и вероисповести у Монархији и није суштински мењала устаљену праксу основног школства. Међутим, успели су да подигну образовни ниво малобројних учитеља, затим свештеника и прошире школску мрежу отварајући и прве средње школе код Срба. Посебно место међу јерарсима заслужним за развој школства заузима поменути митрополит Павле јер је у његовој просветној политици уочљиво да у појединим питањима настоји да прати, тада актуелну, реформску просветну политику Беча. Прихватајући тековине просветитељског правца, митрополит Павле је у посланицама свештенству истицао корисност образовања. ${ }^{12}$ Настојао је да обезбеди материјалну основу за развој образовања, што је учинио оснивањем Клирикалног фонда ${ }^{13}$, затим добар учитељски кадар и отварање школа које би Србима омогућиле стицање практичних знања и знања неопходних за напредовање у животу. У том циљу отворио је 1749. у Сремским Карловцима Покровобогородичну школу у којој су се образовали и монаси, што је била несумњива новина у Српској цркви. Иако се после митрополитове смрти 1768. ова школа угасила, њен значај и утицај су били изузетни, већ и по томе што су учитељи и свештеници који су се у њој образовали могли да народу у наредном периоду предоче значај просвете. У Срему, митрополитској архидијецези, најбоље се осетио утицај ове школе, јер су се ту пред крај митрополитовог живота и у наредном периоду школе брже отваране, а за наставу су ангажовани управо бивши ђаци Покровобогородичне школе. ${ }^{14}$ Такође, заслужан је и за оживљавање недељних школа, што је први пут захтевао од свештенства $1754 .{ }^{15}$ Чињеница да је на подручју архидијецезе пред крај митрополитовог живота било више световњака него свештеника учитеља још једном наглашава прихватање рационалистичке

\footnotetext{
${ }^{12}$ О овоме вид.: Никола Гавриловић, Српско школство у Хабзбуршкој монархији у другој половини ХVIII века, Историја школа и образовања код Срба, Београд 1974, 120-122; уопштено о посланицама митрополита Павла Ненадовића: Дамаскин Грданички, Посланице митрополита Павла Ненадовића (1699-1768), Богословље, IV-1, Београд 1929, 7-36; Димитрије Руварац, Позиви и одзиви или радња појединих српских архиепископа у митрополији карловачкој, око подизања српских школа и стварања фондова за ґихово издржавање, Земун 1894, 9-18.

${ }^{13}$ Први назив овог фонда био је Касе Покрово-Богородичних школа Архиепископије Митрополије, из чега je могуће закључити да је прва намена фонда била да издржава покровобогородичне школе у Карловцима. Основна намена је брзо измењена па је фонд служио у знатно шире сврхе, Димитрије Руварац, Покрово-богородичне школе у Карловиима (1749. -1769.), Сремски Карловци 1926, 5; Милош Рајић износи тврдњу да је фонд основан због карловачких школа, те да је то разлог зашто је митрополит рачунао само на прилоге из Архидијецезе. Вид.: Милошъ Раићъ, Србски народни фондови, Карловци 1864, 4-6; Димитрије Руварац, Позиви и одзиви..., 13-14.

${ }^{14}$ Димитрије Руварац, Покрово-богородичне школе у Карловцима, 3-42.

${ }^{15}$ Ове школе су радиле недељом и празницима, а предвиђене су пре свега за старије људе, које су свештеници учили основним црквеним учењима и молитвама, Дамаскин Грданички, нав. дело, 31-32.
} 
филозофије од стране митрополита, али и његово познавање реформског правца у образовном систему Монархије. ${ }^{16}$

Реформа школства код Срба била је само једна у низу реформи спроведених седамдесетих година XVIII, које су имале далекосежне последице не само на правно-политички положај Срба већ и на развој духовног живота. Реформе су спроведене преко два Регуламента (из 1770. и 1777), ${ }^{17}$ затим Деклараторије (1779) и Конзисторијалне системе (1782). Једна од мера тада донетих било је отварање штампарије за дела штампана ћирилицом, што је имало позитивног одраза на ширење књиге међу Србима. Дошло је до редукције црквених празника, одређен је однос између митрополита и епископа. Наглашено је да митрополитима припада искључиво духовна власт, што је најбољи пример сужавања Привилегија. Тако је српска аутономија у Хабзбуршкој монархији сведена на ниво црквено-просветне. ${ }^{18}$

Друга фаза реформе српског школства почела је већ на расправно-изборном сабору 1769. Следећи инструкције које је добио из Беча, царски комесар генерал гроф Андрија Хадик покренуо је на Црквено-народном сабору држаном 1769. расправу о финансирању школа. ${ }^{19}$ Несумњиво је да треба тражити извесну паралелу између, са једне стране, настојања да се у Монархији укидањем језуитског реда и узимањем њихове имовине створи економска основа школске реформе и, са друге стране, покушаја на овом сабору да се од црквене имовине, тачније Даљског спахилука, створи фонд за финансирање српских школа. Клирикални фонд, који је основао митрополит Павле Ненадовић, и даље је био фонд из којег је финансирана Покровобогородичина школа, јер је приликом његовог оснивања одређено да је то фонд само ове школе, а тек је у наредном периоду промењена његова сврха. Расправа је поведена и о заоставштини будимског епископа Дионисија Новаковића

\footnotetext{
${ }^{16}$ АСАНУК, МПА „Б“ 1767/90.

${ }^{17}$ Иако су Регуламенти доношењем Деклараторије стављени ван снаге, суштински није дошло до неке промене јер су најзначајнији параграфи ових докумената нашли се и у Деклараторији, Дејан Микавица, Српско питање на Угарском сабору 1690-1918, Нови Сад 2011, 38.

${ }^{18}$ Дејан Микавица, Владан Гавриловић, Горан Васин, Знаменита документа за историју српског народа 1538-1918, Нови Сад 2007, 94-117; Дејан Микавица, нав. дело, 37-39.

${ }^{19}$ Дозволу за расправни црквено-народни сабор успео је да издејствује митрополит Павле Ненадовић, али, после његове смрти пре почетка рада, сабор је постао изборно-расправни. Сукоб између клера и представника власти почео је одмах после митрополитове смрти, нарочито када је на његовој сахрани акламацијом за администратора седисвакантне митрополије изабран бачки епископ Мојсије Путник. Сматрајући да право постављања митрополијског администратора има само Двор, поништена је ова одлука и за администратора је постављен вршачки епископ Јован Георгијевић. Иако је епископ Мојсије био личност блиска Двору, радило се о праву које није смело бити нарушено једним преседаном. Сабор је радио од 4. маја до 7. октобра 1769. пошто је због митрополитове смрти био одложен. Једно од главних питања о којима се расправљало на сабору било је питање прихода, дисциплине и финансија свештенства. Главну опозицију вољи Двора представљао је темишварски епископ Вићентије Јовановић Видак. На овом сабору поново је требало бранити право слободног избора митрополита, а претресане су и оптужбе против црквених великодостојника, нарочито епископа Видака, који је ослобођен оптужби, а за митрополита је изабран администратор епископ Јован Георгијевић. Важно је напоменути да се међу захтевима који су изнети на овом сабору налазио и захтев да се православној деци дозволи похађање католичких школа, што је заиста и учињено Школским уставом 1776, Јохан Хајнрих Швикер, Политичка историја Срба у Угарској, Нови Сад - Београд 2005, 181-201.
} 
(процењеној на 21.000 форинти) коју је по комесаровом плану требало искористити за школски фонд. Иако је о финансијском питању расправљано на укупно четири седнице, никаква одлука није донета. ${ }^{20}$ Незадовољан начином на који се финансирају српске основне школе, ${ }^{21}$ гроф Хадик је од цивилних и војних власти тражио детаљније извештаје. Тек је на крају саборских заседања било речи и о отварању школа, али не у виду расправе већ само у виду закључка, односно царског рескрипта који је прочитан Сабору. У њему је стајала царичина жеља да у сваком месту постоји мала (основна) школа - ради тога је упућено питање цивилним и војним властима како се могу финансирати учитељи и школе - док би у епархијским средиштима могла постојати и „велика школа“, иако није било најјасније који тип школа се подразумевао под овим изразом. Није чудно зато што је гроф Хадик тражио писмено обавештење о школовању свештенства. ${ }^{22}$ На крају се поново прешло на финансијско питање у коме се тражи да се из Клирикалног фонда исплаћују учитељске плате, али не и зидање школа. ${ }^{23}$ Искуство овог сабора у вези са школством представљало је основу за настанак 65. и 66. параграфа Регуламента, донетог 27. септембра 1770. У овим параграфима истакнут је значај школе за развој нације и најављено оснивање ћирилске штампарије у Бечу у којој би били штампани уџбеници за православне школе. Иако тиме није решено школско питање, поменути параграфи наговестили су нову културну еру код Срба. ${ }^{24}$

До доношења Школског устава 1776. којим је коначно решено питање реформе тривијалних српских школа у Банату, систематски, у складу са реформским замахом Беча, радило се и на реформи код српског и румунског становништва у Банату. ${ }^{25}$ Значај овог акта је вишеструк, како зато што су школе у Банату добиле ново уређење тако и што је овај акт постао основа за уређење и свих осталих школа православаца изван Баната. Импулси за реформу су долазили из

\footnotetext{
${ }^{20}$ Било је то: 22. маја, 28. јуна, 7. и 23. августа. О овоме: С. Костић, Реорганизаиија школа у духу просветитељских реформи, Историја школа и образовања код Срба, Београд 1974, 161; Ђорђе Рајковић, Српски народни сабор 1769. у Карловцчима, Српски летопис, књига 114, Нови Сад 1872, 160, 165, 172, 176-177.

${ }^{21}$ У одговору који је Сабор дао комесару наведено је да се школе издржавају од школских кутија које су се налазиле у црквама, да се делом финансирају од пореза који је купљен међу парохијанима у појединим општинама и да се школе у Карловцима (овде се мислило на више школе односно Покровобогородичну) издржавају прилозима епархија и цркава, односно из Клирикалног (школског) фонда, Јохан Хајнрих Швикер, нав. дело, 188-189.

${ }^{22}$ Исто, 189.

${ }^{23}$ С. Костић, Реорганизација..., 161.

${ }^{24}$ Philip J. Adler, Habsburg School Reform Among the Ortodox Minorities, 1770-1780, Slavic Review, 33, 1974, 27-28.

${ }^{25}$ У Бечу су решили да реформу православног основног школства прво спроведу у Банату, за шта је постојало више разлога. Пре свега, Банат је у просветном погледу био на веома ниском степену у односу на друге области Монархије, док је, истовремено, још увек био камерални посед неинкорпориран у Угарску. Беч је школску реформу спроводио систематски прво у Наследним земљама и областима које су се налазиле под његовом директном управом, а затим у другим деловима царства. Како су за Војну границу већ важили закони као у Наследним земљама, једина област у којој су живели Срби изван надлежности Угарске, у којој се већ радило на реформи школства, био је Банат, Н. Гавриловић, Срби и Румуни, Нови Сад 1997, 170.
} 
Беча, нарочито Илирске дворске депутације, ${ }^{26}$ којој је препуштено да изврши реформу, али под надзором Двора. У овом „министарству за српска питања“ више пута је вођена расправа како да се побољша и реформише основно школство православних поданика у Банату. Циљ је био да се школство реформише на истим основама као у Наследним земљама, односно онако како је замишљено да се то учини за читаву Монархију, а то је значило по једнообразном принципу за све вере и народе. Због тога је на основу предлога из 1769 , који је ради реформе школа у Банату саставио Данијел Лазарини, ${ }^{27}$ и искуства последњег црквено-народног сабора, на седници Илирске дворске депутације, одржаној 22. априла 1770, а на иницијативу дворских реформских кругова, референт Адам фон Вајнгартен упутио предлог за реформу православних школа по угледу на Наследне земље и постављање једне особе у звању директора банатских школа која би је спровела у дело. У првом тренутку се помишљало на Данијела Лазаринија, који је и постављен на то место, али никада није преузео дужност јер је премештен на друго место. Готово две године је протекло док није поново почело са расправама о овом питању, односно док Банатска земаљска администрација није 14. марта 1772. затражила од митрополита Јован Георгијевића да препоручи за директора банатских тривијалних школа погодну личност. У одговору који је митрополит упутио 15. априла стајала су три имена Данијел Лазарини (Данило Лазаревић), Захарија Орфелин и Теодор Јанковић Мирјевски. Лазарини је због сумњивог живота као могући директор одмах изостављен. Орфелин је постављао тешке захтеве пред Администрацију за своје ангажовање, ${ }^{28}$ док је Јанковић препоручен и од стране председника Администрације грофа Кларија оцењен као најпогоднија личност, те је одлучено да њему припадне овај положај. ${ }^{29}$

Пошто је постављен за директора банатских тривијалних школа, Теодор Јанковић је уз инструкције и савете Илирске дворске депутације и реформског круга око царице Марије Терезије, у време 1773-1776. настојао да српско школство у Банату добије сасвим нов облик. Да је у томе имао успеха види се већ из чињенице

\footnotetext{
${ }^{26}$ Основана је 1745. под називом Илирска дворска комисија као одговор на захтеве Срба изнете на Црквено-народном сабору из 1744. Назив Илирска дворска депутација добила је 1747. и под њим је остала до укидања. Била је висока политичка установа за Србе, изједначена са осталим дворским канцеларијама у Бечу. На челу јој нису били Срби, али је одиграла веома значајну улогу у развоју српске политичке, културне и националне свести. Укинута је 2. децембра 1777, Владан Гавриловић, Темишварски сабор и Илирска дворска канцеларија (1790-1792), Нови Сад 2005, 37-41.

${ }^{27}$ Предлагао је да се у свакој већој општини отвори основна школа у којој би се предавало писање, читање, рачунање и катихизис. Родитељи који не би слали децу у школу били би додатно опорезовани. Предлагао је да у Темишвару буде отворена једна виша школа за ученике који би да наставе школовање. Такође, да напише буквар за тривијалне школе и да буде постављен за школског инспектора. Од ових предлога прихваћено је само да напише буквар, мада није објављен. О овоме: Д. Кириловић, Српске..., 28.

${ }^{28}$ У својим захтевима је истицао да би био и директор немачких тривијалних школа (мада њихов број није био велик) и да му због тога морају дати две плате. Поред тога тражио је по једног канцеларисту за немачи и румунски језик, као и једног писара за српски. Такође, тражио је да му дају посебну накнаду за инспекцију школа, коју ће обављати два пута годишње, за шта би требало да има обезбеђене кочије, Тихомир Остојић, Захарија Орфелин живот и рад му, Београд 1923, 62-63.

${ }^{29}$ Исто, 63; Н. Гавриловић, Срби и Румуни, 169-178.
} 
да је у Банату 1768. било 66 основних школа, а до 1776. отворено је 117 нових, при чему је већину отворио управо Мирјевски. ${ }^{30}$ Уз већ поменуте инстанце и особе које су радиле на поправљању школства, о овоме се расправљало и на црквено-народним саборима и синодима. Већ почетком 1774. била су спремна Упутства за побољшане православних српских и румунских основних икола (Regulae directivae für die Verbesserung des illyrischen und walachischen nicht-unirten Elementaroder Trivial-Schulwesens in den K. K. Erbländern), ${ }^{31}$ као основа реформе банатских тривијалних школа, те је текст упућен Црквено-народном сабору који се састао у Карловцима да изабере новог поглавара Српске цркве после смрти митрополита Јована Георгијевића. Комесару на овом сабору, команданту Славонске војне границе, фелдмаршал-лајтнанту грофу Андреасу фон Матезену наређено је, у инструкцији, да упозна Сабор са Упутствима, о чему је касније расправљано и на Синоду који се састао одмах после Сабора. ${ }^{32}$ Податак који се нашао у овом документу открива колико је школа требало, на основу броја парохија, сазидати, обновити или проширити. Тако је одређено да се сазидају (и отворе) 373 нове школе, да се оправке изврше на 21, а да се 19 прошири. Већ је тада одређено да се учитељима мора одредити дупла окућница (doppelten Hausgrund), као и део плате који би био исплаћиван у новцу или прехрамбеним производима. За подизање школских зграда предвиђено је да становници села обезбеде грађу у државним шумама, односно да држава да сировину, а становници радну снагу. Надзор који је овде одређен већ је био исти као онај који је одређен у Allgemeine Schulordnung-y, донетом крајем 1774. За набавку школског прибора требало је искористити прилог који је за школе оставио покојни епископ будимски Дионисије Новаковић. Царица је одредила и годишњу државну помоћ за школе у Вршачкој и Темишварској епископији од по 1500 форинти. ${ }^{33}$

На основу Упутстава могао је Теодор Јанковић Мирјевски да крене у реформу и отварање школа по Банату, али се показало као веома битно да дође у Беч и ту у Фелбигеровој Нормалној школи заврши курс, чиме би постао

\footnotetext{
${ }^{30}$ Године 1802. тај број се попео на 406, Emanuel Turczynski, Von der Aufklärung zum Frühliberalismus, 34.

31 Упутство садржи 52 параграфа, којима се препоручује отварање тривијалних школа или оправка оронулих зграда, прописани су одређени стандарди школских објеката, финансирање учитеља (део у натури, део у новцу), наставни предмети (Читање, Писање, Рачунање, Катихизис и Појање), а одређени су и школски надзорни органи. Текст овог документа погледати у: Н. Гавриловић, Сpnске..., 287-299.

32 Тако је 8. јануара 1775. било речи о плацу, раду и финансирању Новосадске гимназије (у документу стоји израз „Гимназијум в кр. вароши Новом Саду“, мада се ради о Рождествено-богородичној школи коју је основао владика бачки Висарион Павловић 1731. Она, иако није у свом називу имала реч гимназија, по класама које су у њој постојале, била је у потпуности једнака са тадашњим гимназијама које су постојале у целој Монархији), али и о отварању Семинарије за свештенике у Темишвару. Такође, истог дана је тражено да се изаберу особе које ће преправити или написати уџбенике за све наставне предмете, највероватније за основне (тривијалне) школе јер су у Комисију која је о томе имала да ради одређени Теодор Јанковић и Марко Сервиски, обојица познаваоци школских прилика, и Јован Мишкатировић, који је у каснијем периоду био борац за очување народног идентитета управо кроз основно школство. У то време је већ Јанковић преводио Ручну књигу (Handbuch), што је истакнуто на истој седници, Димитрије Руварац, Рад синодски 1774. и 1775, Српски Сион, 22, Сремски Карловци 1903, 677-678; Васа Стајић, Српска православна велика гимназија у Новом Саду, Нови Сад 1949, 53-66. ${ }^{33}$ J. А. von Helfert, нав. дело, 440-444.
} 
квалификован за место на коме се налази и држање наставе за будуће учитеље. Ово је постало актуелније када је донет и Allgemeine Schulordnung. Ипак, на његов одлазак се чекало скоро три године. У међувремену је Илирска дворска депутција израдила Школски устав за православне тривијалне мале школе у провинцијалном делу Тамишког Баната. Овај документ је написан на основу ранијих уредби и аката који су се тицали школства православних, а царица га је санкционисала 2. новембра 1776. Сада је похађање нормалног курса за Јанковића постао императив, за шта му је Двор обезбедио значајна финансијска средства. Међутим, он није био само слушалац Фелбигеровог нормалног течаја, напротив, постао је творац исправљене и побољшане Фелбигерове Методике, обавезног уџбеника за све будуће учитеље. ${ }^{34}$ Јанковић је увиђао неке недостатке Методике, а како је њему било поверено превођење ове књиге на српски језик, ${ }^{35}$ настојао је да отклони те недостатке, чиме је стекао наклоност реформских кругова. ${ }^{36}$ Чињеница да није био само пасивни слушалац нормалног курса била је позната не само каснијим писцима и историчарима већ његовим савременицима, те је за свој труд добио признање опата Фелбигера и награду од саме царице Марије Терезије. ${ }^{37}$

Доношење и потврда Школског устава одиграли су се у време док је у Карловцима заседао Синод (21. септембар 1776 - 3. јануар 1777), тако да су епископи и митрополит Вићентије Јовановић Видак са њим одмах били упознати. ${ }^{38}$ Овим документом је у великој мери изведена секуларизација школства и увођење савремених педагошких принципа у наставу. Свештенство, како католичко тако и православно, и даље је остало присутно у нижим и вишим школским надзорним органима. Ипак, и овакво присуство духовног елемента било је револуционарно у односу на претходно стање када се образовање, нарочито основно, налазило искључиво у рукама Цркве, са веома малим утицајем световног елемента. Бригу о просвети сада је водила држава, она је постала њен Politicum. Тако је према Школском уставу у свакој православној црквеној општини требало сазидати

\footnotetext{
${ }^{34}$ Фелбигер је о њему оставио следеће запажање: „Његово изванредно схватање суштине прописаног побољшања школства у свим деловима наставе и темељно познавање наставних предмета дају основа нади да ће он на најбољи начин управљати школама које му се поверавају и да ће их довести до жељеног степана савршенства“, С. Костић, Реорганизација..., 165.

35 Пун назив овог дела на српском гласи: Роучная книга потребная Магїстрюмъ Иллурїческихъ Nеунїтскихъ мальхх школь въ Цесаро-Кралевскихъ госоударствахъ, а на немачком: Nothwendiges Handbuch für Schulmeister der illyrischen nicht unirten Trivial-Schulen in den Kais. Königlichten Erblandern, С. Костић, нав. дело, 168.

${ }^{36}$ Сматрао је да деца не треба да уче напамет текстове из читанке или катихизис, као ни молитве, које иначе сваког дана наглас изговарају у школи. У преписци између Чешко-аустријске дворске канцеларије и Илирске дворске депутације договорено је да се задржи табеларни Фелбигеров метод, али са извесним изменама, у којем би се, уместо писања само почетних слова речи, писала цела почетна реч реченице. Учење напамет и даље је представљало и у реформисаном школству начин усвајања градива, С. Костић, нав. дело, 168.

${ }^{37}$ J. А. von Helfert, нав. дело, 442-445; Д. Кириловић, Српске школе..., 30-32; Мита Костић, Гроф Колер као културнопросветни реформатор код Срба у Угарској у ХVIII веку, Београд 1932, 110.

${ }^{38}$ J. A. von Helfert, нав. дело, 446.
} 
школску зграду према одређеним грађевинским и санитарним прописима. ${ }^{39}$ Било је предвиђено да мушка и женска деца седе одвојено, а православној деци дозвољено је да могу ићи и у католичке школе. ${ }^{40}$ Штавише, ако није било православне парохије у конфесионално мешовитом насељу, онда су православна деца морала да похађају католичке школе, у чему је Школски устав био изричит. У чак осам параграфа овог закона (11-18 §) регулисан је положај учитеља. Управо су то параграфи којима је спроведена секуларизација школства. Учитељи су могли бити само православни и католички становници Монархије световног сталежа, ${ }^{41}$ који добро познају предмете и методику наставе предмета који се предају у школама. Само изузетно, у недостатку другог решења, то су могла да буду свештена лица, али су тада и она, као и световна, морала да имају потврду за бављење учитељским послом директора нормалне школе, што је значило да су завршили нормални течај. У већим општинама, поред учитеља могао је да буде ангажован и учитељски помоћник, а сви су они морали да имају по примерак Фелбигерове Методике у Јанковићевом преводу. ${ }^{42}$ Материјално стање учитеља делимично је регулисано овим законом, јер је прописано да поред двоструке окућнице (ова мера је иста као у Упутствима из 1774) мора да добије од општине и два јутра ливаде. Међутим, плата која ће му бити исплаћена у новцу није унета у закон, ${ }^{43}$ већ се тај износ препуштао договору између учитеља и општине, ради чега су морали да сачине уговор који је подношен на оверу управних власти. Овим законом прописани су и предмети који су се предавали у школи - у потпуности у складу са предметима који су за тривијалне школе прописани Allgemeine Schulordnung-ом - те су се учили читање, писање, рачунање и основе вере (катихизис). Препоручено је учитељима да поједину децу

\footnotetext{
39 За ову сврху бесплатно је добијана дрвена грађа, С. Костић, нав. дело, 166; Д. Кириловић, Српске..., 82-83.

${ }^{40}$ Ова одредба стајала је већ у предлогу Школског устава, који је у односу на коначну верзију претрпео велике промене. На њеном задржавању инсистирао је школски референт и саветник Дворске школске комисије Кес, сматрајући да ће, уколико католичке школе буду боље и привуку део православне деце, тиме бити омогућено приближавање припадника различитих конфесија и олакшан продор уније, Д. Кириловић, нав. дело, 37-38.

${ }^{41}$ Ова одредба имала је две последице - учитељи нису могли бити протестанти и нису могли долазити из неке друге државе. Ово се првенствено односило на руске учитеље, а у складу је са политиком прекидања српско-руских веза и све присутнијом српском културном оријентацијом ка Бечу. О овоме: Мита Костић, Гроф Колер..., 118; Ако би страни поданик хтео да постане учитељ у Хабзбуршкој монархији, морао је најпре да у њој проведе 10 година, а подразумевало се да је морао и имати потврду директора нормалне школе за бављење учитељским послом, Д. Кириловић, нав. дело, 88-89.

${ }^{42}$ Најпре је било предвиђено да учитеље поставља Школска комисија, а плаћа општина. Међутим, током расправе о Школском уставу утврђено је да је боље да се следи пракса која постоји у Наследним земљама, да учитеља бира и плаћа општина. Надзор над избором учитеља обезбеђен је одредбом да општина може да га ангажује само ако има потврду директора школе за бављење учитељским позивом. Кес је интервенисао и поводом питања ко треба да издаје ове потврде, сматрајући да је то посао школског директора, а не Школске комисије пред којом учитељ полаже испите, Исто, 38-39.

${ }^{43}$ У Упутствима параграфом 18. тачно је назначена плата која се имала исплаћивати у новцу. Ту је предвиђено да село које има до 60 кућа учитеља плаћа 30 форинти, ако село има између 60 и 100 домаћинстава, учитељска плата је износила 40 ф., а ако је имало преко 100 домаћинстава, плата је била 60 форинти, Н. Гавриловић, Србске.., 290.
} 
настоје да науче и немачки, што ће бити посебно цењено, али учење тог језика није било прописано као обавезно. Ова одредба се може сагледавати из две перспективе. Са једне стране, она се уклапа у централистичку и германизаторску политику Марије Терезије и њеног сина цара Јосифа II, док је, са друге стране, имала за Србе практичну корист јер им се пружала могућност да уче језик који им је обезбеђивао могућност даљег школовања и напредовања, те, у крајњој линији, бољу материјалну егзистенцију. Док се са данашње тачке гледишта прва перспектива може сагледавати као негативна појава, друга има позитивну конотацију и несумњив културолошки значај.

Уџбеници чије коришћење је било предвиђено у настави већ су у време доношења овог закона били штампани у Курцбековој штампарији. Били су то, пре свега, Катихизис Јована Рајића, учитељски приручник Ручнаја књига и Буквар. На крају закона одређен је узраст у коме деца имају да посећују школу - од шесте до девете године, ${ }^{44}$ док је од девете до дванаесте било предвиђено да недељом и празником посећују тзв. повторне школе (мера је била донесена ради утврђивања градива и његовог трајног усвајања). Последњим параграфом, посвећеним школском надзору, било је предвиђено да у селима свештеник са представником световне власти има право месечног обиласка и надзора школе, протопрезвитер са једним чланом из свог протопрезвитерата требало је да врши тромесечни надзор, док су епископи са школским директором надзор, односно обилазак, вршили једном годишње. Следећа инстанца била је Илирска дворска депутација, а иза ње се налазила Дворска школска комисија. Присуство духовних лица у школском надзору јасно сведочи да секуларизација школа није извршена у потпуности, али ова лица нису била самостални надзорници и у том погледу нема никакве разлике између школства православаца у Банату и школства у Наследним земљама. Међутим, секуларизација је Школским уставом у православним тривијалним школама добила већи замах него у истим немачким школама. Наиме, док су у немачким наставу из предмета вере изводила духовна лица-катихете, дотле су у православним тривијалним школама и ову наставу изводили учитељи, а свештенство је могло само да врши надзор над предавањима. ${ }^{45}$ На овај начин, једним законским актом који са данашње тачке гледишта у извесним цртама показује напредак у односу на Allgemeine Schulordnung, а нарочито наглашава секуларизацију, решено је питање реформе православних тривијалних школа у Тамишком Банату. ${ }^{46}$

\footnotetext{
${ }^{44}$ У самом Уставу је стајало „Родители дожни суть деты своя шестое оуже лето возраста своег достигшія даже до девятагш ихъ лета...въ школу послати...“ чиме је макар декларативно назначено да је основна школа обавезна за децу оба пола, Кириловић, Српске школе.., 97.

${ }^{4}$ у предлогу Школског устава стајало је да ће наставу из предмета Вере, као и у немачким и у православним школама, држати катихета. Међутим, интервенцијом Кеса овај предлог је измењен. Као разлоге за то Кес је навео слабу образованост православног свештенства, што је делимично било тачно, али и настојање да се народ одвоји од утицаја таквог свештенства. У аргументима изнетим поводом овог питања Кес није помињао верске разлоге или омогућавање уније, већ се користио пре свега педагошким аргументима, мада није сигурно колико је био искрен у својим настојањима, Исто, 39.

${ }^{46}$ Исто, 29-42, 81-101; С. Костић, Реорганизација..., 162-164, 166-167.
} 
Пошто је Allgemeine Schulordnung-ом решено питање школске реформе за Наследне земље и Војну границу, а Школским уставом за територију Тамишког Баната, остало је још да се школска реформа изврши на територији Угарске. За ову територију такође је примењен Фелбигеров систем, који је прилагодио члан Угарске дворске канцеларије Јожеф Ирмењхази. ${ }^{47}$ Закон, објављен под називом Ratio educationis totiusque rei litterariae per regnum Hungariae et provincias eadem adnexas, Марија Терезија је санкционисала 22. августа 1777. Њиме је читава територија Угарске подељена на девет школских округа, који се нису поклапали са црквеним дијецезама. Важност овог закона за Србе је утолико већа што је исте године када је он донесен укинута Илирска дворска депутација (2. децембар 1777), а послови који су спадали у њену надлежност пренети су на Угарску дворску канцеларију. Пре него што је укинута Илирска дворска депутација постигнут је договор између ње и Угарске дворске канцеларије у вези са православним школама у Угарској (без Баната) са Хрватском и Славонијом, по коме је Школски устав остао најважнији закон по којем се морају уређивати школе православних у целој провинцијалној Угарској. ${ }^{48}$ По доношењу Ratio educationis-a успостављени су школски окрузи на чијем челу су се нашли школски директори, који су истовремено били директори нормалних школа у којима су школовани учитељи и врховни инспектори округа. У сваком округу је постојала само једна нормална школа, али су за православне организоване посебне и то у оквиру главних, градских школа. Од девет школских округа за Србе су била значајна три: ${ }^{49}$

1. Великоварадски - обухвата Банат са седиштем у Темишвару;

2. Загребачки - обухвата Хрватску, Славонију и Срем;

3. Печујски - обухвата територију Бачке, Барање и према северу све територије на којима је било српских школа.

У сваком школском округу, па и у ова три, постојали су школска комисија и врховни школски надзорник. Православни директори су били потчињени католичким школским директорима. У Великоварадском округу директор је био Теодор Јанковић Мирјевски, у Печујском је за директора постављен Аврам Мразовић (седиште у Сомбору) а у Загребачком Стефан Вујановски (седиште у Осеку). Мразовић и Вујановски су такође били полазници Фелбигерове Норме (са њима је полазник био и Марко Сервиски). Они су 1778. постављени за школске

\footnotetext{
${ }^{47}$ Петар Рокаи, Золтан Ђере, Тибор Пал, Александар Касаш, Историја Мађара, Београд 2002, 354, 364-365.

${ }^{48}$ Резолуцијом од 29. новембра 1777, насталом договором између Угарске дворске канцеларије и Илирске дворске депутације, одлучено је да се православне школе на територији Угарске уреде на основу Ratio educationis-а, али по узору на банатске школе. О овоме: Antun Cuvaj, Građa za povijest školstva Kraljevina Hrvatske i Slavonije od najstarijih vremena do danas: Od najstarijih vremena do godine 1835, Zagreb 1907, 465.

${ }^{49}$ С. Костић, Реорганизација..., 188-190.
} 
директоре, а међу првим пословима које су морали да изврше било је отварање нормалних школа и образовање учитеља. ${ }^{50}$

На основу три законска акта - Allgemeine Schulordnung-a, Школског устава и Ratio educationis-a, извршена је реформа школства у Хабзбуршкој монархији. Поред ових искључиво школских закона, којима су спроведени секуларизација и подржављење школа, постоји и неколико закона значајних за српско школство који нису донети у циљу корените реформе, али су се појединим деловима дотакли и школског питања. Хронолошки гледано први законски акт настао после 1777. у коме се налази и регулатива важећа за школство била је Деклараторија донета 16. јула 1779. Први пут се питање школства у овом документу дотиче посредно у 34. параграфу. У њему се инсистира да будући свештеници треба да имају одређено образовање, те да о томе морају да поднесу писмене потврде приликом постављања у парохијама. Поред тога, Конзисторија је приликом напредовања у чиновима морала да испитује свештено лице и увери се у његово познавање наука потребних за вршење свештеничке службе. Иако се у овом параграфу нигде не помињу школе, јасно је да су њиме постављени извесни образовни стандарди свештеничког позива. ${ }^{51}$ Конкретније о школству говори се у параграфу 57 , који се односи на тривијалне школе у Војној граници, а који је у ствари потврда једног ранијег акта (од 27. марта 1771) којим се саветује граничарским властима да оснивају немачке тривијалне школе. $^{52}$

После доношења Ratio educationis-а из 1777. све до 1805. нису доношени законски акти који су се тицали искључиво питања просвете, мада је било аката који су се поред других питања бавили и питањем школства, каква је поменута Деклараторија. Први законски акт који се односио искључиво на школство после 1777. био је Politische Verfassung der deutschen Volksschulen für die $k$. $k$. Österreichischen Provinzen или скраћено Politische Schulverfassung, објављен 11. августа 1805. На територији на којој су живели Срби он је у овом облику важио за Наследне земље и Војну границу. Следеће године донесен је нови Ratio educationis publicae totiusque rei litterariae per regnum Hungariae et provincias eadem adnexas, који је побољшао и појаснио одредбе из предходног Ratio educationis-a. Mеђутим, овим законима није спроведена озбиљнија реформа у српском школству, већ је то учињено тек 1811. делатношћу Уроша Несторовића. ${ }^{53}$

Током епохе просвећености десиле су се многе значајне промене у сфери духовног живота. Реформа образовног система изведена под утицајем просветитељских мислилаца са нескривеном жељом владара да секуларизују образовање и ставе га под државни надзор, била је једна од тековина XVIII века која

\footnotetext{
${ }^{50}$ Исто, 189.

${ }^{51}$ Јован Радонић, Мита Костић, Српске привилегије од 1690 до 1792, Београд 1954, 139.

${ }^{52}$ Исто, 146; Никола Гавриловић, Реорганизација школа у Војној граници, Историја школа и образовања код Срба, Београд 1974, 202.

${ }^{53}$ Antun Cuvaj, нав. дело, 638-649, 776-791; Јован Савковић, Преглед постанка, развитка и развојачења Војне границе (од XVI века до 1873. године), Нови Сад 1964, 67-68; Славко Гавриловић, Основни граничарски закон из 1807 (1808) године, ЗМСИ, 38, Нови Сад 1988, 139-141; Јован Радонић, Мита Костић, нав. дело, 139-140; Дејан Микавица, Владан Гавриловић, Горан Васин, нав. дело, 161-200.
} 
је касније утицала на развој националне свести. Српски народ, који је у овом веку живео и даље под влашћу туђих владара, није имао једнак духовни развој. У том погледу су се најбрже развијали они који су живели у Хабзбуршкој монархији, што је са једне стране била последица културног развоја саме Монархије, а са друге потребе српског народа да се уклопи у нове политичке и културне оквире, те да кроз прихватање западних тековина боље очува свој народни и верски идентитет. Реформа основног школства коју је у Хабзбуршкој монархији извео опат Фелбигер оставила је дубок траг у школству свих народа ове државе. Код Срба је ова реформа пратила просветну политику Беча, што је приметно још од времена када је на челу Карловачке митролије био митрополит Павле Ненадовић, а нарочито од његове смрти 1768, односно од Црквено-народног сабора из 1769. Управо од ове године почиње реформска политика и у српском школству, чији је носилац, за разлику од претходног периода, Бечки двор и круг људи око царице Марије Терезије. Током наредних осам година извршена је реформа школства најпре у Наследним земљама, потом у Банату и на крају на територији Угарске. Она је код српског народа изведена унеколико успешније, односно квалитетније, него код других народа јер је смањен број текстова који су учени напамет, што је била заслуга банатског школског директора Теодора Јанковића Мирјевског. Секуларизација, главна тековина просветитељских школских реформи, изведена је код српског народа одлучније и дубље у односу на остале народе Монархије. Тако је крајем XVIII века створена добра основа за духовни напредак српског народа у Хабзбуршкој монархији и чврсто упориште за очување верског и народног идентитета.

Извори и литература:

АСАНУК, МПА „Б“ 1767/90.

Adler, Philip J., Habsburg School Reform Among the Ortodox Minorities, 1770-1780, Slavic Review, 33, 1974.

Андерсон, Метју С., Европа у осамнаестом веку 1713-1789, Београд 2003.

Beales, Derek Edvard Dawson, Joseph II: in the shadow of Maria Theresia, 1741-1780, 1987.

Гавриловић, Владан, Темишварски сабор и Илирска дворска канцеларија (1790-1792), Нови Сад 2005.

Гавриловић, Никола, Реорганизација школа у Војној граници, Историја школа и образовања код Срба, Београд 1974.

Гавриловић, Никола, Срби и Румуни, Нови Сад 1997.

Гавриловић, Славко, Основни граничарски закон из 1807 (1808) године, ЗМСИ, 38, Нови Сад 1988.

Грданички, Дамаскин, Посланище митрополита Павла Ненадовића (1699-1768), Богословље, IV-1, Београд 1929.

Kann, Robert A., A history of the Habsburg Empire 1526-1918, Barkly - Los Angeles London, 1980. 
Кириловић, Димитрије, Српске основне школе у Војводини у 18 веку (1740-1780), Сремски Карловци 1929.

Костић, Мита, Гроф Колер као културнопросветни реформатор код Срба у Угарској у XVIII веку, Београд 1932.

Костић, Страхиња, Реорганизачија школа у духу просветитељских реформи, Историја школа и образовања код Срба, Београд 1974.

Melton, James Van Horn, The Theresian School Reform of 1774, Early modern Europe, Malden-Oxford-Victoria 2006

Микавица, Дејан, Гавриловић Владан, Васин Горан, Знаменита документа за историју српског народа 1538-1918, Нови Сад 2007.

Микавица, Дејан, Српско питање на Угарском сабору 1690-1918, Нови Сад 2011.

Neugebauer, Wolfgang, Schule und Absolutismus in Preussen, Berlin 1992.

Остојић, Тихомир, Захарија Орфелин живот и рад му, Београд 1923

Раићъ, Милошъ, Србски народни фондови, Карловци 1864.

Радонић, Јован, Мита Костић, Српске привилегије од 1690 до 1792, Београд 1954.

Рајковић, Ђорђе, Српски народни сабор 1769. у Карловцима, Српски летопис, књига 114, Нови Сад 1872.

Рокаи, Петар, Ђере Золтан, Пал Тибор, Касаш Александар, Историја Мађара, Београд 2002.

Руварац, Димитрије, Позиви и одзиви или радња појединих српских архиепископа у митрополији карловачкој, око подизања српских школа и стварања фондова за ғихово издржавање, Земун 1894.

Руварац, Димитрије, Рад синодски 1774. и 1775, Српски Сион, 22, Сремски Карловци 1903.

Руварац, Димитрије, Покрово-богородичне школе у Карловиима (1749. -1769.), Сремски Карловци 1926.

Савковић, Јован, Преглед постанка, развитка и развојачења Војне границе (од XVI века до 1873. године), Нови Сад 1964.

Стајић, Васа, Српска православна велика гимназија у Новом Саду, Нови Сад 1949.

Turczynski, Emanuel, Von der Aufklärung zum Frühliberalismus, Munchen-Oldenburg 1985.

Hadživuković, Stevan, Francusko prosvetiteljstvo odraz vere u ljudski napredak, Novi Sad 2005.

Helfert, Joseph Alexander, Die Gründung der österreichischen Vollksschile durch Maria Theresia, Prag 1860.

Cuvaj, Antun, Građa za povijest školstva Kraljevina Hrvatske i Slavonije od najstarijih vremena do danas: Od najstarijih vremena do godine 1835, Zagreb 1907.

Швикер, Јохан Хајнрих, Политичка историја Срба у Угарској, Нови Сад - Београд 2005.

Schermaier, Josef, Geschichte und Gegenwart des allgemeinbildenden Schulwesens in Österreich, Wien 1990. 
NENAD NINKOVIĆ

\section{THE REFORM OF SERBIAN SCHOOL SYSTEM IN THE HABSBURG MONARCHY 1769-1777}

Results of the reforms in the seventies of the eighteenth century, which were implemented by the will of Vienna throughout the Habsburg monarchy, were that the education system went under the supervision of the state, and the school was secularized to a great extent. This was the case with the Serbian primary schools as well, which were reformed between 1769 and 1777, what made a good basis for expanding the school network and improving the instruction. Implementation of these measures was entrusted to the school principals, Teodor Janković Mirjevski, Stefan Vujanovski and Avram Mrazović, in which they had a lot of success. Unlike the rest of the Monarchy, the church supported the school reform in Serbs with its considerable influence. However, the secularization in the educational process in Serbs was implemented more decisive and deeper than in other nations.

Keywords: school reform, Allgemeine Schulordnung, School Constitution, Ratio Educationis, primary schools, Teodor Janković Mirjevski, Stefan Vujanovski, Avram Mrazović. 